(2) Open Access Full Text Article

\title{
Investigations on Acinetophage, QAB 3.4, Targeting Extensively Drug-Resistant Acinetobacter baumannii Isolates
}

\author{
Aamir Hussain ${ }^{1-3}$ \\ Shaheena Kousar ${ }^{2}$ \\ Ihsan Ullah ${ }^{3}$ \\ Aqsa Zulfiqar ${ }^{2}$ \\ Hafiz Arslan Ali ${ }^{2}$ \\ Amina Manzoor ${ }^{2}$ \\ Atif Aziz ${ }^{2}$ \\ Asghar Javaid $\mathbb{D}^{4}$ \\ Mubashar Aziz ${ }^{2}$ \\ Binish Khaliq ${ }^{5}$ \\ Humera Nazir ${ }^{2}$ \\ Aleem Ahmed Khan ${ }^{2}$ \\ Ahmed Akrem ${ }^{2}$ \\ Muhammad Qamar Saeed ${ }^{2}$ \\ 'Combined Military Hospital Multan, \\ Multan, Pakistan; ${ }^{2}$ Dr. Ghulam Nabi \\ Chaudhry Laboratory of Microbial \\ Technologies, Department of \\ Microbiology and Molecular Genetics, \\ Institute of Pure and Applied Biology, \\ Bahauddin Zakariya University, Multan, \\ Pakistan; ${ }^{3}$ Institute of Basic Medical \\ Sciences, Khyber Medical University, \\ Peshawar, Pakistan; ${ }^{4}$ Pathology \\ Department, Nishtar Medical University, \\ Multan, Pakistan; ${ }^{5}$ Institute of Molecular \\ Biology and Biotechnology, The \\ University of Lahore, Lahore, Pakistan
}

Correspondence: Muhammad Qamar Saeed

Dr. Ghulam Nabi Chaudhry Laboratory of Microbial Technologies, Department of

Microbiology, Institute of Pure and Applied

Biology, Bahauddin Zakariya University,

Multan, Pakistan

Tel +92 333-0231 222

Email mqamarsaeed@bzu.edu.pk
Purpose: Drug resistance against antimicrobials is on the rise at alarmingly high rates. Acinetobacter baumannii is one of the six ESKAPE pathogens which are a significant "one health" issue. Clinical isolates of $A$. baumannii exhibit MDR phenotype mostly and infrequently the XDR and PDR phenotype. As a result, these infections have one of the highest mortality rates in hospitals. Alternative therapies are urgently needed.

Methods: Various phages were enriched against XDR clinical strain of A. baumannii. A potent phage, QAB 3.4, was further tested against 100 clinical strains. Because of its broad lytic activity, it was further tested for stability, resistance development and as an infection control agent.

Results: Phage QAB 3.4 showed broad lytic activity against 100 MDR and XDR clinical isolates representing a wide diversity of infection sites. Assays conducted to document the phage's stability, and ability of clinical isolates to develop resistance against it, showed promising outcomes for its potential use in clinical applications. Phage QAB 3.4 was able to eradicate $A$. baumannii from pre-inoculated solid surfaces. It provides a proof of concept that phages can be used as environmentally friendly infection control agents.

Conclusion: We propose the phage QAB 3.4 is a promising candidate for further preclinical and clinical studies to test its biosafety and efficacy.

Keywords: ESKAPE, A. baumannii, bacteriophages, phage therapy, host-range, lytic activity

\section{Introduction}

Antibiotic therapy is used throughout the world for the treatment of infectious diseases caused by various bacterial pathogens. However, some bacterial pathogens display a wide range of resistance against many antibiotics. Some pathogens exhibit resistance to almost all available antibiotics including aminoglycosides, ciprofloxacin, tetracyclines, aminopenicillins and cephalosporins. ${ }^{1}$ Staphylococcus aureus, Enterobacteriaceae, Enterococcus sp. and Acinetobacter baumannii are listed as multidrug-resistant pathogens. ${ }^{2}$

A. baumannii is a gram-negative, non-motile, non-fermentative coccobacillus that is oxidase negative and coagulase positive. It is known to cause nosocomial infection in patients who are exposed to prolonged hospitalization in ICUs and are undergoing extensive use of antibiotics. ${ }^{3}$ It may cause ventilator-acquired pneumonia, complications related to surgery, catheter-related infections of the urinary tract and bloodstream infections. A. baumannii is capable of forming biofilms and 
acquires resistance by modification of the drug's target site, enzymatic inactivation of the drug and increased efflux of the drug out of the bacterial cell and paused influx of the drug. 4

Due to increased resistance, it is an emerging challenge to treat $A$. baumannii infections. Carbapenems were used against multidrug-resistant A. baumannii but some A. baumannii strains are also becoming resistant against carbapenems. ${ }^{5}$ Other antibiotics such as sulbactam, polymyxin and tigecyclines can also be used as effective treatment against $A$. baumannii infections but resistance is prevalent in some strains of $A$. baumannii against these classes of antibiotics. ${ }^{6}$ Colistin is considered as antibiotic of last resort against $A$. baumannii infections but its utilization has been limited due to toxic effects ${ }^{7}$ and some strains have even developed resistance against them. ${ }^{8}$ As a result of increased resistance of $A$. baumannii to a wide range of antibiotics and disinfectants, it is garnering increasingly greater focus from researchers and clinicians. This scenario is forcing them to search for novel therapeutics.

Experiments are being conducted on characterization and utilization of lytic bacteriophages to treat patients suffering from A. baumannii infections. In many studies, A. baumannii strains were isolated from different patients and used as host for lytic phages. These phages are able to kill different strains of $A$. baumannii. These lytic phages were characterized and their genomes were sequenced completely. ${ }^{3,9,10}$ According to some studies, phage exposure results in decreased virulence in remaining bacteria. ${ }^{11}$

Resistance in A. baumannii strains against carbapenem, aminoglycosides and ciprofloxacin has also been reported in Pakistan. ${ }^{5,12}$ There is imminent need of collecting bacteriolytic phages which can target local bacterial isolates. The reported work envisaged to isolate phages effective against multidrug-resistant (MDR) strains of A. baumannii. We report a phage isolate, QAB3.4, which showed broad lytic activity against several clinical MDR and XDR isolates. It exhibited promising properties of clinical significance such as low resistance emergence. Moreover, we demonstrate that our phage isolate was able to efficiently clear bacteria inhabiting solid surfaces in experimental settings.

\section{Materials and Methods}

\section{Bacterial Isolates}

Sampling was carried out between July 2018 to January 2020. Various samples received and confirmed to be Acinetobacter baumannii at Armed Forces Institute of Pathology, Rawalpindi, Pakistan, were used to determine efficiency of our phage. Bacterial identification was ascertained by API 20NE and antibiogram was developed using CLSI methods. One of the isolates (strain 42) was selected to enrich the bacteriophage because it was resistant to all the tested drugs.

\section{Phage Sampling}

Acinetobacter baumannii was cultured on Blood and MacConkey agar plates a day before the start of bacteriophage isolation. For the isolation of bacteriophages, sewage water samples were collected from multiple sites in sterile pre-labeled bottles. Sampling sites included effluents from combined military hospital (CMH) Multan, Nishtar Hospital Multan, Children Hospital Multan and some dairy farms effluent from Multan region.

\section{Phage Enrichment}

A heavy inoculum of sub-cultured Acinetobacter baumannii was prepared from a randomly selected colony on MacConkey agar in a $10 \mathrm{~mL}$ tube by overnight culture. Prelabeled glass flasks were poured with $10 \mathrm{~mL}$ of $2 \mathrm{x}$ LuriaBertani (LB) broth (Oxoid, Catalog no. 0264) followed by addition of $10 \mathrm{~mL}$ sterile sewage samples filtrate and $500 \mu \mathrm{L}$ of bacterial culture. Sewage samples were sterilized using 0.2 $\mu \mathrm{L}$ syringe filters (Corning, Catalog no. 411224). All these flasks were incubated at $37^{\circ} \mathrm{C}$ for $24 \mathrm{~h}$.

After 24 hours, 12-13 mL suspension from each flask was transferred into pre-labelled $15 \mathrm{~mL}$ tubes. After centrifugation of $10 \mathrm{~min}$ at $4200 \mathrm{RPM}$, the supernatant from each tube was syringe filtered. This filtrate was used for two more rounds of enrichment to increase titers of possible anti-acinetoviruses.

\section{Plaque Assay}

After three enrichments, suspected bacteriophagecontaining filtrates were taken and serially diluted 10 times $\left(10^{-1}\right.$ through $\left.10^{-10}\right)$ in sterile saline solution in 10 tubes. An early log phase bacterial inoculum was prepared by adding $300 \mu \mathrm{L}$ of bacterial suspension in $30 \mathrm{~mL} \mathrm{LB}$ broth in a flask, followed by incubating it for $2-4 \mathrm{~h}$ at $37^{\circ} \mathrm{C}$. After that, a mixture of bacterial isolate, bacteriophage dilution and soft LB agar (normal solid media contains $1.5 \%$ agar) was prepared by adding $0.6 \%$ agar in LB broth. For this purpose, $100 \mu \mathrm{L}$ of early log phase inoculum was added into a $20 \mathrm{~mL}$ glass tube followed by the addition of $10 \mu \mathrm{L}$ of each of the 10 phage dilutions. Then 
$20 \mathrm{~mL}$ of soft LB agar was added. All these tubes were incubated at $37^{\circ} \mathrm{C}$ for $20 \mathrm{~min}$ for adsorption to take place.

After that about $8 \mathrm{~mL}$ of the mixture from each tube was poured on pre-labeled LB agar plates and incubated at $37^{\circ} \mathrm{C}$ for $24 \mathrm{~h}$ or until appearance of plaques on phagepositive plates. Plaques were observed and virus titer was calculated by counting plaques on $10^{-7}$ plate.

\section{Host Range Assessment}

Sensitivity of 100 clinical bacterial isolates against phages was determined by agar overlay procedure. Vulnerable strains were titered against phages and plaque forming units were calculated. We compared relative PFU by dividing PFU/mL of the strain 42 with those of other clinical strains (Table 1).

\section{Frequency of Phage Resistant Bacteria}

We calculated frequency of phage-resistant bacteria following methods described in Beale 1984. ${ }^{13}$ One $\mathrm{mL}$ of bacteria at $10^{8} \mathrm{cfu} / \mathrm{mL}$ with definite amount of phage lysate to achieve 100 MOI were mixed. Phage-bacteria mixtures were incubated for $10 \mathrm{~min}$ at $37^{\circ} \mathrm{C}$. Following this, the mixtures were poured on LB agar plates. Plates were incubated overnight at $37^{\circ} \mathrm{C}$. The next day, any emerging colonies were counted. Ratio between no. of plated CFU and no. of colonies recovered after phage exposure was calculated which provided relative rates of resistant emergence.

\section{Phage Stability in Broth}

Phage prep at $1000 \mathrm{PFU} / \mathrm{mL}$ was distributed in three vials of $1 \mathrm{~mL}$ each and one vial was kept at room temperature on the lab bench, the second vial was refrigerated at $4^{\circ} \mathrm{C}$, and the third vial was put in $-21^{\circ} \mathrm{C}$. On days $1,3,7,14$ and $21,10 \mathrm{uL}$ (equivalent to $100 \mathrm{PFU} / \mathrm{mL}$ ) were taken and mixed with appropriate amounts of bacteria in LB soft agar. Agar overlay method was employed and plates were incubated at $37^{\circ} \mathrm{C}$ for $48 \mathrm{~h}$ and plaques were counted.

Additionally, stability of phage activity was determined in LB broth by preparing 10 -fold serial dilution of our phage starting from $100 \mathrm{PFU} / \mathrm{mL}$ to $0.001 \mathrm{PFU} / \mathrm{mL}$. In every dilution $A$. baumannii were added at $10^{5} \mathrm{CFU} / \mathrm{mL}$. Activity of phage and bacteria was examined by determining the OD after incubation period of $48 \mathrm{~h}$ at $37^{\circ} \mathrm{C}$.

\section{Production and Testing of QAB 3.4 Antiserum}

Polyclonal Anti QAB 3.4 antiserum was produced by intra-peritoneal injection of phage in 3-month-old female rabbits. We injected 6 rabbits with filter sterilized $10 \mathrm{~mL}$ suspension containing $1.5 \times 10^{11}$ per $\mathrm{mL}$ phage in LB broth. We calculated phage titer by assuming that an appropriate phage suspension of $1000 \mathrm{PFU} / \mathrm{mL}$ strength for bacterial inoculum of $0.5 \mathrm{McF}$ arland should contain $1.5 \times 10^{11}$ per $\mathrm{mL}$ infectious virus particles. A booster injection was applied after 4 weeks, and blood was collected after 2 weeks of booster injection through the central ear artery. Blood was kept in sterile $50 \mathrm{~mL}$ falcon tubes for $4 \mathrm{~h}$ at room temperature which resulted in clot formation. Serum was collected from these tubes and centrifuged at $4000 \mathrm{rpm}$ at $4^{\circ} \mathrm{C}$ for $10 \mathrm{~min}$ to remove any cellular debris. Serum was stored at $-20^{\circ} \mathrm{C}$ until further use.

We made mixtures of phages with the collected sera to determine neutralizing potential. For this an appropriate amount of phage (equivalent to $10 \mathrm{MOI}$ ) was mixed with varying amounts of antisera $(10 \mathrm{uL}$ to $3 \mathrm{~mL})$. The purpose was to determine the volume of antiserum which completely abolishes phage activity. These mixtures were incubated at $37^{\circ} \mathrm{C}$ for $30 \mathrm{~s}$ before they being mixed with susceptible bacterial strain 42. Only two rabbits yielded potent anti QAB 3.4 sera. One of those sera were selected for use in Acinetobacter Clearance Assay.

\section{Acinetobacter Clearance Assay}

A 0.5 McFarland inoculum of Acinetobacter baumannii was prepared in a $10 \mathrm{~mL}$ tube. Three circles of one-inch diameter each were drawn on a pre-sterilized lab bench surface and labeled as "phenol", "phage" and "saline". Then $2 \mathrm{~mL}$ of bacterial inoculum was poured in each circle. After $20-25 \mathrm{~min}, 250 \mu \mathrm{L}$ of $90 \%$ phenol, normal saline, and bacteriophage suspension was added on respective inoculated circles. Phage was added at $10 \mathrm{MOI}$ (multiplicity of infection: ratio between no. of infectious phage particles and no. of host bacterial cells). The same procedure was adopted for two more surfaces: top of the incubator and office table.

After overnight exposure of inoculated circles with phenol (positive control), saline (negative control) and phage, each circle was flooded and then mixed gently with $0.5 \mathrm{~mL}$ of QAB 3.4 antiserum to neutralize any phage that was still unadsorbed. Remaining bacteria (if any) were collected with a moistened sterile swab by rolling it over each circle thoroughly. Then cotton part of swab was aseptically cut into $10 \mathrm{~mL}$ sterile saline and vortexed to collect bacteria in the saline. Subsequently, 1 uL calibrated loop (SPL Life Sciences, Catalog no. 90001) was dipped into the saline containing inoculum from 
Table I Relative PFU/mL (EOP) and Resistance Frequency of QAB 3.4 in Clinical Strains

\begin{tabular}{|c|c|c|c|c|c|c|c|c|c|}
\hline Sr. No & Source & Sensitive Antibiotics & EOP & RRF & Sr. No & Source & Sensitive Antibiotics & EOP & RRF \\
\hline 1 & Pus & Mino, Pb, Dox, Gen & 1.2 & 0.8 & 52 & Fluid & Dox, Mino, $\mathrm{Pb}$ & I.I & 0.9 \\
\hline 2 & Blood & Mino, Pb, Dox, Gen & I.I & 0.8 & 53 & NBL & Dox, Mino, $\mathrm{Pb}$ & 1.1 & 0.8 \\
\hline 3 & NBL & Mino, Pb, Dox, Gen & I.I & 0.9 & 54 & Tissue & Dox, Mino, Pb, Tgc & 1.1 & 1 \\
\hline 4 & Blood & $\mathrm{Pb}$, Mino & 0.8 & 1 & 55 & NBL & Gen, Tgc, Pb, Mino & 0.9 & 1 \\
\hline 5 & $\begin{array}{l}\text { Pus } \\
\text { swab }\end{array}$ & $\mathrm{Pb}, \mathrm{Cot}$ & 0.2 & 1 & 56 & $\begin{array}{l}\text { Pus } \\
\text { swab }\end{array}$ & $\mathrm{Pb}$ & 0.8 & I.I \\
\hline 6 & $\begin{array}{l}\text { Pus } \\
\text { swab }\end{array}$ & Fep, Dox, Tgc, Pb, Amk, Mino & 0.2 & 0.8 & 57 & NBL & $\mathrm{Pb}$ & 0.5 & 0.9 \\
\hline 7 & Sputum & Dox, Mino, $\mathrm{Pb}$ & 0.6 & 0.9 & 58 & EB & $\mathrm{Pb}$ & 0.5 & 1.2 \\
\hline 8 & NBL & $\begin{array}{l}\text { Gen, Imp, Mero, Pb, Dox, } \\
\text { Mino }\end{array}$ & 0.7 & I.I & 59 & Tip & $\mathrm{Pb}$, Tgc, Mino & 0.7 & 1 \\
\hline 9 & Blood & $\begin{array}{l}\text { Cip, Imp, Mero, Pb, Tgc, Amk, } \\
\text { Gen, Min, Dox, Cot }\end{array}$ & 0.4 & 1.2 & 60 & Fluid & Pb, Dox, Mino & 0.6 & 1.2 \\
\hline 10 & CVP tip & $\mathrm{Pb}$ & 0.7 & 1.2 & 61 & Fluid & Pb, Dox, Mino & 0.6 & 1.3 \\
\hline II & Sputum & Dox, Mino, $\mathrm{Pb}$ & 0.7 & 1.2 & 62 & Sputum & $\begin{array}{l}\text { Dox, Imp, Mero, Gen, Cip, Cot, } \\
\text { Mino, Pb, Tzp, Tgc, Fep, Aug }\end{array}$ & 0.4 & 0.8 \\
\hline 12 & $\begin{array}{l}\text { Pus } \\
\text { swab }\end{array}$ & $\mathrm{Pb}$ & 0.9 & 1.3 & 63 & Tissue & $\begin{array}{l}\text { Dox, Imp, Mero, Gen, Cip, Cot, } \\
\text { Mino, Pb, Tzp, Tgc, Fep, Aug }\end{array}$ & 0.8 & 1.2 \\
\hline 13 & Pus & Gen, Ami, Cot, Imp, Mero & 0.4 & I.I & 64 & Blood & Tgc, Dox, Pb & 0.8 & I.I \\
\hline 14 & Blood & Mino, $\mathrm{Pb}$ & 0.5 & 1 & 65 & Tissue & $\mathrm{Pb}, \mathrm{Tgc}$ & 0.9 & 1 \\
\hline 15 & NBL & Ami, Dox, Pb, Mino & 0.6 & 0.9 & 66 & Pus & $\mathrm{Pb}$, Mino & 1.1 & I.I \\
\hline 16 & Fluid & Ami, Dox, Pb, Mino & 0.7 & 0.9 & 67 & NBL & Dox, Mino, $\mathrm{Pb}$ & 1 & 1 \\
\hline 17 & NBL & Ami, Dox, Pb, Mino & 0.6 & 0.8 & 68 & Blood & Dox, Mino, Pb & 1.2 & 0.8 \\
\hline 18 & $\begin{array}{l}\text { Pus } \\
\text { swab }\end{array}$ & $\mathrm{Pb}, \mathrm{Tgc}$ & 0.7 & 0.9 & 69 & Tissue & Dox, Mino, $\mathrm{Pb}$ & I.I & 1.2 \\
\hline 19 & NBL & Tgc, Pb, Mino & 1.2 & I & 70 & Tip & $\mathrm{Pb}$ & 1.2 & 1.3 \\
\hline 20 & NBL & Tgc, Pb, Mino, Dox & 0.9 & 0.9 & 71 & NBL & $\mathrm{Pb}, \mathrm{Tgc}$ & 1.2 & 0.8 \\
\hline 21 & Tip C/S & $\mathrm{Pb}$ & 0.9 & 0.8 & 72 & Tissue & $\mathrm{Pb}, \mathrm{Tgc}$ & 1.2 & I.I \\
\hline 22 & Bile & $\begin{array}{l}\text { Tgc, Pb, Mino, Gen, Ami, Cip, } \\
\text { Cot, Tzp }\end{array}$ & 0.5 & 0.9 & 73 & PI Fluid & Dox, Mino, $\mathrm{Pb}$ & 1.2 & 0.8 \\
\hline 23 & NBL & Dox, Pb, Mino & 0.5 & I & 74 & Tip & Dox, Mino, $\mathrm{Pb}$ & 1.4 & 0.9 \\
\hline 24 & Urine & Cot, Imp, Mino & 0.4 & I & 75 & Tissue & $\mathrm{Pb}, \mathrm{Amk}$ & I.I & I \\
\hline 25 & Pus & $\mathrm{Pb}$ & 0.8 & 0.9 & 76 & Tissue & NONE & 0.3 & 1.3 \\
\hline 26 & Sputum & $\mathrm{Pb}$ & 0.9 & 0.8 & 77 & Tissue & $\mathrm{Pb}$ & 1.2 & I.I \\
\hline 27 & $\begin{array}{l}\text { Pus } \\
\text { swab }\end{array}$ & Cot, $\mathrm{Pb}$, Mino & 0.4 & 0.8 & 78 & $\begin{array}{l}\text { Pus } \\
\text { swab }\end{array}$ & $\mathrm{Pb}$ & 0.8 & 0.9 \\
\hline
\end{tabular}

(Continued) 
Table I (Continued).

\begin{tabular}{|c|c|c|c|c|c|c|c|c|c|}
\hline Sr. No & Source & Sensitive Antibiotics & EOP & RRF & Sr. No & Source & Sensitive Antibiotics & EOP & RRF \\
\hline 28 & Fluid & $\begin{array}{l}\text { Dox, Tgc, Pb, Mino, Gen, Cip, } \\
\text { Tzp, Ami, Cot }\end{array}$ & 0.4 & 0.8 & 79 & $\begin{array}{l}\text { Pus } \\
\text { swab }\end{array}$ & $\mathrm{Pb}$ & 1.4 & 0.9 \\
\hline 29 & $\begin{array}{l}\text { Pus } \\
\text { swab }\end{array}$ & $\mathrm{Pb}$ & I.I & 0.9 & 80 & $\begin{array}{l}\text { Pus } \\
\text { swab }\end{array}$ & $\mathrm{Pb}$ & 1.2 & 1.3 \\
\hline 30 & NBL & $\mathrm{Pb}$ & I.I & 0.8 & 81 & NBL & $\mathrm{Pb}$ & 1.3 & 0.8 \\
\hline 31 & NBL & Dox, Pb, Mino & 1.2 & I & 82 & CVP tip & Dox, Mino, Pb, Tgc & 0.8 & 1.2 \\
\hline 32 & Pus & Dox, Pb, Mino, Gen & 0.8 & 1.1 & 83 & Pus & Dox, Mino, Pb, Gen & 0.7 & 1.2 \\
\hline 33 & $\begin{array}{l}\text { Pus } \\
\text { swab }\end{array}$ & Gen, Dox, Cot, Pb, Mino & 0.8 & 1.1 & 84 & EBW & Tgc, Pb, Mino & 0.7 & 0.8 \\
\hline 34 & Pus & $\mathrm{Pb}$ & 0.8 & 1.2 & 85 & EBW & Pb, Mino, Dox, Cot, Tgc & 0.6 & 0.9 \\
\hline 35 & Pus & Gen, Cot, Dox, Pb & 0.9 & 1.3 & 86 & $\begin{array}{l}\text { Pus } \\
\text { swab }\end{array}$ & Dox, Mino, $\mathrm{Pb}$ & 0.7 & I.I \\
\hline 36 & EBW & $\mathrm{Pb}$, Dox, Mino & 0.8 & 1.3 & 87 & $\begin{array}{l}\text { Pus } \\
\text { swab }\end{array}$ & Gen, Ami, Dox, Pb, Mino, Tgc & 0.7 & 1.3 \\
\hline 37 & Tissue & Gen, Cot, Dox Pb, Mino, Tgc & 0.6 & 1.2 & 88 & $\begin{array}{l}\text { Pus } \\
\text { swab }\end{array}$ & Tgc, $\mathrm{Pb}$ & 0.9 & 1.3 \\
\hline 38 & Pus C/S & $\mathrm{Pb}$ & 1.3 & 1.3 & 89 & $\begin{array}{l}\text { Pus } \\
\text { swab }\end{array}$ & Dox, Mino & 0.9 & I.I \\
\hline 39 & Tissue & Mino, Cot, $\mathrm{Pb}$ & 1.2 & 1.2 & 90 & NBL & Gen, Dox, Pb, Mino & 1 & I \\
\hline 40 & Tip & Gen, $\mathrm{Pb}$ & 1 & I & 91 & $\begin{array}{l}\text { Pus } \\
\text { swab }\end{array}$ & Dox, Mino, Pb & 1 & 1.2 \\
\hline 41 & NBL & $\mathrm{Pb}$ & I.I & I & 92 & NBL & $\mathrm{Pb}$ & I.I & 0.9 \\
\hline 42 & $\begin{array}{l}\text { Pus } \\
\text { swab }\end{array}$ & $\mathrm{Pb}$ & 1 & 1 & 93 & NBL & $\mathrm{Pb}$ & 0.7 & I \\
\hline 43 & NBL & Tgc & 0.2 & 0.9 & 94 & NBL & $\mathrm{Pb}$, Mino & 0.8 & 1.3 \\
\hline 44 & CSF & $\mathrm{Pb}$ & 0.7 & 1.1 & 95 & Tissue & $\mathrm{Pb}$ & 1.1 & 1.3 \\
\hline 45 & Tissue & Dox, Pb, Mino & 0.6 & 0.9 & 96 & $\begin{array}{l}\text { Pus } \\
\text { swab }\end{array}$ & Dox, Mino, Pb, Gen & 1.1 & 1.1 \\
\hline 46 & $\begin{array}{l}\text { Pus } \\
\text { swab }\end{array}$ & $\mathrm{Pb}$ & I.I & 0.8 & 97 & Tissue & Mino, $\mathrm{Pb}$ & 1 & 0.9 \\
\hline 47 & Tissue & $\begin{array}{l}\text { Gen, Cip, Cef, Tzp, Cot, Ami, } \\
\text { Imp, Mero, Pb, Mino }\end{array}$ & 0.3 & 0.8 & 98 & Sputum & Gen, Mino, Pb, Dox & 0.7 & 0.9 \\
\hline 48 & NBL & Cot, Dox & 0.6 & 0.9 & 99 & NBL & Gen, Mino, Pb, Dox & 0.9 & 1 \\
\hline 49 & NBL & Dox, $\mathrm{Pb}$ & 0.7 & 0.9 & 100 & NBL & $\mathrm{Pb}$, Mino & 0.9 & 1 \\
\hline 50 & Pus & $\mathrm{Pb}$ & 0.8 & 0.8 & 101 & NBL & Pb, Dox, Mino & 1.3 & 1.3 \\
\hline
\end{tabular}

Abbreviations: Mino, Minocycline; Pb, Polymyxin B; Dox, Doxycycline; Gen, Gentamicin; Cot, Sulfamethoxazole; Fep, Cefepime; Tgc, Tigecycline; Amk, Amikacin; Cip, Ciprofloxacin; Imp, Imipenem; Mero, Meropenem; Tzp, Piperacillin - Tazobactam; Aug, Amoxycillin - Clavulanic Acid. 


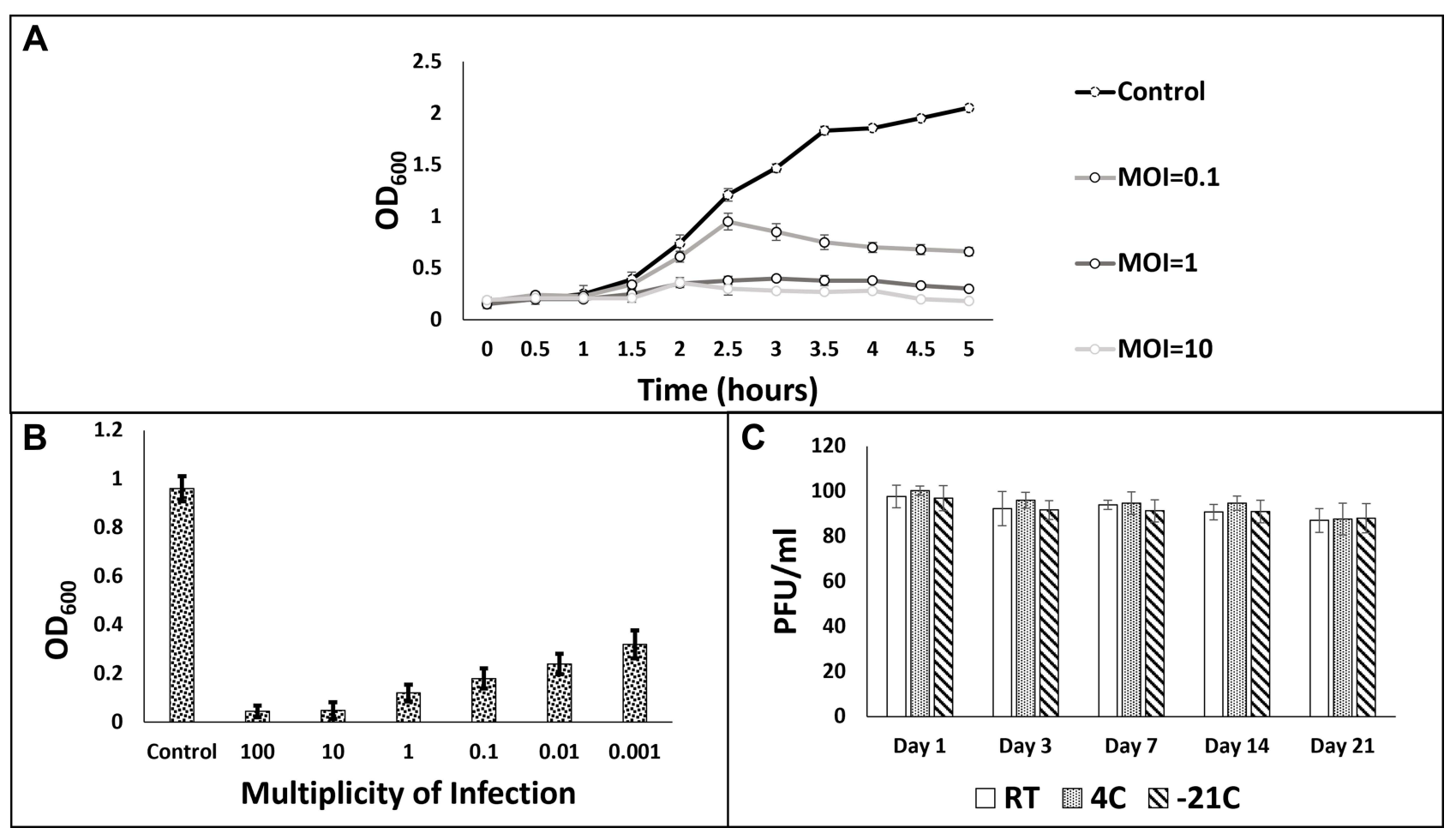

Figure I Phage-Bacteria co-culture assays. A: Bacterial growth curves at various MOI. B: Bacterial growth after $48 \mathrm{~h}$ of phage-bacteria co-culture. C: Phage stability test at various storage temperatures.

circles and LB agar plates were semi-quantitatively streaked. Colonies from phenol-exposed, saline-exposed and phage-exposed circles were counted to determine the bactericidal effects of phage.

\section{Results}

\section{Titration}

We collected some 150 sewage samples from various sites and six samples from Children Hospital Multan, Pakistan yielded bacteriophage on A. baumannii strain 42 (Table 1). Strain 42 was isolated from a pus swab of a patient and was selected as a host for phage enrichment because it was resistant to all antibiotics except "colistin". For phage purification, single isolated plaques were picked and subjected to enrichment. After every round of enrichment, isolated plaques were collected, and the process was repeated three times in order to get a pure single type of phage. Among the six phages, QAB3.4 exhibited broad host range and therefore was selected for further analysis.

QAB3.4 titer was measured in terms of plaque-forming units per milliliter. PFU/mL gives us infectious titer and hence approximate number of "physically fit" particles. Plates containing $10^{-7}$ dilution of phage were used to count plaques as these had isolated and hence countable plaques. All work was done in triplicate and averages were calculated. PFU/mL were extrapolated from the plaque count to be $2 \times 10^{12}$. This high titer phage preparation was used in further experiments.

\section{Bacterial Growth and Resistance Analysis}

Bacterial growth was observed in LB broth in the presence and absence of phage. For this, phage mixtures with bacteria were made at different MOI. To analyze growth patterns, $200 \mathrm{uL}$ of each growth mixture and control were taken and turbidity was measured at regular intervals. Peak turbidity of negative control reached $\sim 2$. None of the mixtures with phage grew beyond the turbidity of $\sim 1$. At the lowest phage-bacteria ratio of $0.1 \mathrm{MOI}$, peak OD was slightly higher than 0.5 (Figure 1A).

In another similar setting, decline in bacterial growth was determined after $48 \mathrm{~h}$ at MOI ranging from 0.001 to 100 by comparing with control (uninfected bacteria). The absorbance of negative control was observed to be around $\sim 1$. Phage-bacteria co-cultures resulted in significant drop in turbidity. Highest turbidity examined at $0.001 \mathrm{MOI}$ equaled 0.32 whereas lowest turbidity was observed to be 0.045 at $100 \mathrm{MOI}$ (Figure 1B).

Phage efficacy under easily maintainable conditions is of vital importance if they are to have clinical applications. 
We analyzed stability of phage prep at $100 \mathrm{PFU} / \mathrm{mL}$ under various temperatures. We could not detect any significant loss of infectivity under various temperatures over the period of 21 days (Figure 1C).

We also quantified possible emergence of resistant colonies in mixtures of phage and strain 42. Resistant frequency (RF) in the $A$. baumannii strain 42 was observed to be $1.8 \pm 0.7 \times 10^{-7}$. We also analyzed resistance emergence in our clinical isolates. Then, relative RF was calculated by dividing RF obtained for clinical isolate to that of strain 42 (Table 1). Relative resistance frequency (RRF) ranged between 0.8 to 1.3 (a number greater than 1 indicates higher RF as compared with strain 42). We could not find any statistical correlation with antibiotic resistance level and resistance frequency.

\section{Phage Efficacy on Clinical Strains}

We sampled 100 clinical isolates of $A$. baumannii to assess lytic activity of phage QAB 3.4. Phage titer in strain 42 was taken as the standard to analyze the relative PFU $/ \mathrm{mL}$ in those strains. We show that our phage exhibited broad lytic activity. However relative $\mathrm{PFU} / \mathrm{mL}$ varied greatly among the tested strains. We also failed to see any correlation between resistance to antibiotics with resistance/susceptibility to phage QAB 3.4. In around $75 \%$ of the assayed strains, the phage exhibited at least $70 \%$ effectiveness compared with the strain 42 . Only in 5\% strains, the phage showed up to $70 \%$ reduction in activity in terms of relative reduction in PFU/mL (Table 1).

\section{Bacterial Clearance Assay}

We set out to determine the potential of our acinetophage isolate in clearing clinically relevant XDR Acinetobacter strain from solid surfaces. For our experiment, we decided to mimic conditions that are common to hospital-inhabiting pathogens. We inoculated different solid surfaces with XDR Acinetobacter baumannii strain in known quantities and applied our phage on those surfaces to determine its clearing potential. We infected our bacterial inoculums at 10 MOI. Same volumes of $90 \%$ phenol and normal saline were used to serve as positive and negative controls respectively. The purpose was to observe the effectiveness of phage compared with phenol which is an established bactericidal.

After overnight exposure to phage, phenol and saline, we collected any remaining bacteria from those surfaces and cultured on LB agar plates in a quantitative manner using calibrated $1 \mathrm{uL}$ loops. Therefore, colony count
Table 2 Colony Forming Units (CFU/ $\mu \mathrm{L}$ ) of Acinetobacter baumannii from Phenol-, Saline- and Phage-Exposed Surfaces

\begin{tabular}{|l|l|l|l|}
\hline Surface & Phenol & Phage & Saline \\
\hline Lab Bench & 4 & 12 & 87 \\
\hline Top of Incubator & 3 & 18 & 101 \\
\hline Office Table & 6 & 15 & 112 \\
\hline Avg士SD & $\mathbf{4 . 3 \pm 1 . 6}$ & $15 \pm 3$ & $100 \pm 12.5$ \\
\hline
\end{tabular}

represented CFU per microliter after the exposure of our bactericidal agents.

We observed that phenol, quite expectedly, was the most efficient antibacterial as its exposure resulted in least number of CFU from all three surfaces: 4, 3 and 6 from lab bench, incubator top and office table, respectively. Saline-exposed surfaces gave much higher colony count (87, 101 and $112 \mathrm{CFU} / \mathrm{uL}$ for three surfaces in above-mentioned order). Phage-exposed surfaces gave 12,18 and $15 \mathrm{CFU} / \mathrm{uL}$ which, although a higher number when compared with phenol, is significantly smaller than in the case of saline treatment (Table 2).

\section{Discussion}

A. baumannii is associated with several superficial and systemic infections, particularly in ICU settings. ${ }^{14}$ Its remarkable success as a nosocomial pathogen has been attributed to its exceptional survivability in unfavorable conditions. ${ }^{15}$ Its persistence coupled with alarmingly high rates of resistance to antibiotics is a cause of great concern for medical establishments worldwide. Our work shows that phages (or phagederived products) can be used as disinfectants. Unlike phenols, they are environmentally friendly and self-limiting.

Colonies appearing from phenol and phage-exposed samples were sporadic. They were not neatly present on the streaked area, rather, they were randomly located on the plates. It can, therefore, be concluded that those colonies did not necessarily originate from inoculated surfaces and may have grown from accidental trapping of bacteria from the incubator environment. Why, then, did we not see a similar number of nonspecific colonies in both phage and phenol-exposed inoculums? This apparent anomaly can be explained on the basis of broad-spectrum effect of phenol but not phage. As swabs were used to collect bacteria from inoculated surfaces (as explained in Materials and Methods), they could have also carried traces of phenol and phages along with bacteria. When these were subsequently cultured on LB plates, phenol and phages (albeit, 
in small quantities) would have entered in the plates. Any bacteria entering from the incubator environment would have been killed by the broad-spectrum effect of phenol but not by a narrow-spectrum phage, resulting in more colonies in the latter case.

One highly desirable feature for a therapeutic phage is broad host range. Phage QAB 3.4 was able to infect almost all the tested clinical strains albeit with variable efficacy (Table 1). It is noteworthy that infection assays using PFU are considered very reliable because they tend to sometimes underestimate the infection-causing ability of phages and therefore plaquing ability, even if low, is a good indicator for ascertaining host range. ${ }^{16}$ On tests designed to monitor phage efficacy under various conditions, QAB 3.4 also showed good promise. Overall, this phage is the right candidate to be further investigated for potential clinical use.

Stability under various storage conditions is very important if phages are to have any clinical application. A suitable medical product should be storable in already available hospital storage facilities. In third world countries such as Pakistan, not all hospitals have ultra-low temperature storage facilities. Keeping this in mind, we explored whether or not phage loses its efficacy under easily storable conditions. Phage stocks in LB broth, made in $15 \mathrm{~mL}$ plastic tubes and encased in opaque boxes, remained stable for as long as 21 days. We conducted an experiment to see the potential of resistance against our phage which was found to be low. We compared $\mathrm{RF}$ in strain 42 to that seen in our clinical isolates. We observed relative RF well within the acceptable limits. ${ }^{13}$ It must however be emphasized that such lab assays have limited predictive value. In this backdrop, host-parasite co-evolutionary studies have the potential to yield valuable insights for not only medical applications of phages but also in other areas. Design of such experiments should be guided by high-throughput genetic analyses of virus and bacteria.

\section{Conclusion}

In our view, this phage should be tested in animal models to determine toxicity issues, if any. Additionally, thorough genomic studies are also needed to alleviate any safety concerns as well as open doors for targeted genetic engineering to improve efficacy, host range and to possibly avoid emergence of resistant bacterial clones.

\section{Ethical Approval}

Ethical approval was sought from ethics committee of Institute of Pure and Applied Biology, Bahauddin
Zakariya University Multan for the purpose of antiserum production in rabbits.

We adopted guidelines established in The Welfare of Laboratory Animals. ${ }^{17}$ Rabbits were kept in a $10 \times 12$ square feet air-conditioned room with rice straw padding. Ambient temperature was maintained between $20-28^{\circ} \mathrm{C}$. After inoculation, rabbits' temperature was periodically monitored. Rabbits room was thoroughly cleaned and disinfected every 10 days. Drinking water was replaced twice daily.

\section{Acknowledgment}

This research was funded by annual research grant of BZU and departmental grant from Khyber Medical University.

\section{Disclosure}

The authors report no conflicts of interest in this work.

\section{References}

1. Perez F, Hujer AM, Hujer KM, Decker BK, Rather PN, Bonomo RA. Global challenge of multidrug-resistant Acinetobacter baumannii. Antimicrob Agents Chemother. 2007;51(10):3471-3484. doi:10.1128/ AAC.01464-06

2. Magiorakos A-P, Srinivasan A, Carey RB, et al. Multidrug-resistant, extensively drug-resistant and pandrug-resistant bacteria: an international expert proposal for interim standard definitions for acquired resistance. Clin Microbiol Infect. 2012;18(3):268-281. doi:10.1111/ j.1469-0691.2011.03570.x

3. Popova AV, Zhilenkov EL, Myakinina VP, Krasilnikova VM, Volozhantsev NV. Isolation and characterization of wide host range lytic bacteriophage AP22 infecting Acinetobacter baumannii. FEMS Microbiol Lett. 2012;332(1):40-46. doi:10.1111/j.1574-6968.2012.02573.x

4. Baptista PV, McCusker MP, Carvalho A, et al. Nano-strategies to fight multidrug resistant bacteria-“A battle of the titans.". Front Microbiol. 2018;9:1441. doi:10.3389/fmicb.2018.01441

5. Hamidian M, Nigro SJ. Emergence, molecular mechanisms and global spread of carbapenem-resistant Acinetobacter baumannii. Microb Genom. 2019;5(10). doi:10.1099/mgen.0.000306

6. Navon-Venezia S, Leavitt A, Carmeli Y. High tigecycline resistance in multidrug-resistant Acinetobacter baumannii. $J$ Antimicrob Chemother. 2007;59(4):772-774. doi:10.1093/jac/dkm018

7. Al-Kadmy IMS, Ibrahim SA, Al-Saryi N, Aziz SN, Besinis A, Hetta HF. Prevalence of genes involved in colistin resistance in Acinetobacter baumannii: first report from Iraq. Microb Drug Resist. 2020;26(6):616-622. doi:10.1089/mdr.2019.0243

8. Cai Y, Chai D, Wang R, Liang B, Bai N. Colistin resistance of Acinetobacter baumannii: clinical reports, mechanisms and antimicrobial strategies. J Antimicrob Chemother. 2012;67(7):1607-1615. doi:10.1093/jac/dks084

9. Lin N-T, Chiou P-Y, Chang K-C, Chen L-K, Lai M-J. Isolation and characterization of $\phi \mathrm{AB} 2$ : a novel bacteriophage of Acinetobacter baumannii. Res Microbiol. 2010;161(4):308-314. doi:10.1016/j. resmic.2010.03.007

10. Yang H, Liang L, Lin S, Jia S. Isolation and characterization of a virulent bacteriophage $\mathrm{AB} 1$ of Acinetobacter baumannii. $B M C$ Microbiol. 2010;10(1):131. doi:10.1186/1471-2180-10-131

11. Regeimbal JM, Jacobs AC, Corey BW, et al. Personalized therapeutic cocktail of wild environmental phages rescues mice from Acinetobacter baumannii wound infections. Antimicrob Agents Chemother. 2016;60(10):5806-5816. doi:10.1128/AAC.02877-15 
12. Taj Z, Rasool MH, Almatroudi A, Saqalein M, Khurshid M Extensively drug-resistant Acinetobacter baumannii belonging to international clone II from a pet cat with urinary tract infection; The first report from Pakistan. Pol J Microbiol. 2020;69 (2):231-234. doi:10.33073/pjm-2020-017

13. Beale GH. A method for the measurement of mutation rate from phage sensitivity to phage resistance in Escherichia coli. $J$ Gen Microbiol. 1948;2(2):131-142. doi:10.1099/00221287-2-2-131

14. Lee C-R, Lee JH, Park M, et al. Biology of Acinetobacter baumannii: pathogenesis, antibiotic resistance mechanisms, and prospective treatment options. Front Cell Infect Microbiol. 2017;7. doi:10.3389/ fcimb.2017.00055
15. Jawad A, Seifert H, Snelling AM, Heritage J, Hawkey PM. Survival of Acinetobacter baumannii on dry surfaces: comparison of outbreak and sporadic isolates. J Clin Microbiol. 1998;36(7):1938-1941. doi:10.1128/JCM.36.7.1938-1941.1998

16. Ross A, Ward S, Hyman P. More is better: selecting for broad host range bacteriophages. Front Microbiol. 2016;7:1352. doi:10.3389/ fmicb.2016.01352

17. Kaliste E, editor. The Welfare of Laboratory Animals. Springer Netherlands; 2007. doi:10.1007/978-1-4020-2271-5

\section{Publish your work in this journal}

Infection and Drug Resistance is an international, peer-reviewed openaccess journal that focuses on the optimal treatment of infection (bacterial, fungal and viral) and the development and institution of preventive strategies to minimize the development and spread of resistance. The journal is specifically concerned with the epidemiology of antibiotic resistance and the mechanisms of resistance development and diffusion in both hospitals and the community. The manuscript management system is completely online and includes a very quick and fair peerreview system, which is all easy to use. Visit http://www.dovepress.com/ testimonials.php to read real quotes from published authors. 